\title{
Comparative Analysis of the Changes of Socioeconomic Risks Caused by the COVID-19 pandemic in Ukraine and the EU Countries
}

\author{
By Olga Novikova ${ }^{1}$, Olena Khandii ${ }^{2}$, Larisa Shamileva ${ }^{1}$
}

\begin{abstract}
The unwillingness of the health care system of different countries to counteract the spread of the COVID-19 virus in 2020 caused the introduction of quarantine restrictions by many countries, which had both positive and negative socioeconomic consequences. The economic consequences include the decrease in production and income of enterprises of almost all types of economic activity, increase in the number of unprofitable enterprises, closure and temporary suspension of small and mediumsized businesses, decline in real GDP. The economic consequences have led to the increase in intensity and manifestation of negative social consequences, including the increase in unemployment and social insecurity, scale and level of citizen poverty, decline in incomes and loss of working time. Influenced by the social and economic negative factors hindering sustainable development, caused by the COVID-19 pandemic, socioeconomic risks in the social and labor sphere have intensified. The article suggests the methodological support for assessing the change of socioeconomic risks in the system of social and labor relations in Ukraine and the EU countries using quantitative assessment methods. The comparison of risks in the social and labor sphere of different countries allows to choose the prioritized directions of influence and effective tools to control and counteract the manifestation of risks, taking into account the experience of other countries.
\end{abstract}

Keywords: socioeconomic risks, COVID-19, labor market, loss of working time, socio-labor relations

\section{Introduction}

The quarantine restrictions in the European countries related to the counteraction of COVID-19 spread have had the negative social and economic consequences, which will further impact the economy, make it difficult to restore balance in the labor market, limit opportunities for sustainable development. The state measures to preserve and protect the country's social resources from the COVID-19 spread, in addition to improving the provision and coverage of medical services, vaccines and medicines, included the restrictions of human rights to freedom of movement, freedom of meeting, temporary prohibition or restrictions on the activities of enterprises in the sphere of trade, transport, tourism, catering, culture, entertainment and recreation and many others. As a result, the spheres where the introduction of remote forms of work is impossible, there was a significant reduction in the need for labor and its release, decline in employee incomes, increase in working time and the number of cases of labor rights violations. The significant transformations have occurred in the system of social and labor relations, influenced by both positive and negative economic actions and social phenomena, as well as the labor 
market occasions.

The study of the crisis phenomena in the socioeconomic sphere during the COVID-19 pandemic in the context of threats to the sustainable development of countries has been the subject matter of study of many researchers (Bragazzi et al. 2020; Mahase 2020; Roper 2020; Tran et al. 2020; Yadav et al. 2020). The most relevant works today are those dedicated to finding answers to the challenges in the social and labor sphere, overcoming the growing risks of unemployment and poverty. This study aims to assess the socioeconomic risks caused by the COVID-19 pandemic and to conduct a comparative analysis of them in the EU countries and Ukraine.

\subsection{Economic consequences of the COVID-19 pandemic}

According to the IMF forecasts, due to the economic recession in 2020, world GDP is expected to fall by $3.0 \%$ (KMU 2020). The real negative trends of the economic recession turned out to be even worse than it was forecasted. For example, in the EU countries for Q1 2020, due to the financial crisis, the decline in GDP was 3.7\% (in \% to the previous quarter), while in $\mathrm{Q} 2-11.8 \%$, and in the first half of the year this decline reached $15.06 \%$ (Table 1$)$.

Table 1. The indicators of changes in socioeconomic risks in the system of social and labor relations in Ukraine and the EU countries

\begin{tabular}{|c|c|c|c|c|c|c|c|c|c|}
\hline \multirow[b]{2}{*}{ Indicators } & \multirow[b]{2}{*}{$\begin{array}{l}\text { Impact } \\
\text { directions }\end{array}$} & \multicolumn{3}{|c|}{ EU countries ${ }^{1}$} & \multicolumn{3}{|c|}{ Ukraine $^{2}$} & \multicolumn{2}{|c|}{$\begin{array}{l}\text { Weighting } \\
\text { coefficients }\end{array}$} \\
\hline & & Q1 & Q2 & $\begin{array}{l}\text { I half- } \\
\text { year of } \\
2020\end{array}$ & Q1 & Q2 & $\begin{array}{c}\text { I half-year } \\
\text { of } 2020\end{array}$ & $\mathrm{~W}_{\mathrm{i}}$ & $\mathrm{W}_{\mathrm{ij}}$ \\
\hline \multicolumn{8}{|c|}{ I. The economic conditions of risk formation in the system of social and labor relations } & 0,281 & - \\
\hline $\begin{array}{l}\text { 1. Growth/decrease in real GDP, } \\
\% \text { to the previous quarter, as well } \\
\text { as by the components: }\end{array}$ & stimulator & $-3,7$ & $-11,8$ & $-15,06^{*}$ & $-1,3$ & $-11,4$ & $-12,55^{*}$ & - & 0,25 \\
\hline \begin{tabular}{|l|} 
- household expenditures and \\
final consumption
\end{tabular} & stimulator & $-4,2$ & $-12,4$ & $-16,08^{*}$ & 8,1 & $-10,4$ & $-3,1^{*}$ & - & 0,25 \\
\hline - gross fixed capital formation & stimulator & $-4,6$ & $-17,0$ & $-20,8^{*}$ & $-21,2$ & $-29,5$ & $-44,5^{*}$ & - & 0,25 \\
\hline $\begin{array}{l}\text { 2. Indicator of economic } \\
\text { sentiment, } \% \text { to the previous } \\
\text { quarter }\end{array}$ & destimulator & - & 87,5 & 91,1 & 105,6 & 73,1 & 81,4 & - & 0,25 \\
\hline \multicolumn{8}{|c|}{ II. The main indicators of unemployment risks } & 0,296 & - \\
\hline $\begin{array}{l}\text { 3. Share of those employed in the } \\
\text { industries most affected by } \\
\text { quarantine }\end{array}$ & stimulator & - & 0,421 & 0,427 & - & 0,602 & 0,602 & - & 0,392 \\
\hline $\begin{array}{l}\text { 4. Unemployment rate (according } \\
\text { to ILO criterion), } \%\end{array}$ & stimulator & 6,3 & 7,9 & 7,1 & 8,6 & 9,9 & \multirow{2}{*}{$\begin{array}{c}17,0 \\
\text { (average } \\
\text { score) }\end{array}$} & \multirow{2}{*}{ - } & \multirow{2}{*}{0,128} \\
\hline \begin{tabular}{|l|} 
4.1. Unemployment rate \\
(according to expert estimates), \%
\end{tabular} & stimulator & - & - & - & - & 24,0 & & & \\
\hline $\begin{array}{l}\text { 4.2. Hidden unemployment rate } \\
\text { (part-time or under- employment, } \\
\text { unpaid leave, etc.), } \%\end{array}$ & stimulator & - & 17,0 & 15,0 & - & 19,7 & 19,7 & - & 0,122 \\
\hline
\end{tabular}

${ }^{1}$ Calculated on the basis of statistical data presented in the work (Employment-quarterly...2020)

${ }^{2}$ Calculated according to the State Statistics Service of Ukraine, the State Employment Service of Ukraine and the NBU Inflation Reports. 


\begin{tabular}{|c|c|c|c|c|c|c|c|c|c|}
\hline 4.3. Remote employment, $\%$ & destimulator & - & 27,0 & 27,0 & - & 29,0 & 29,0 & - & 0,179 \\
\hline 4.4. Informal employment, $\%$ & stimulator & - & 20,9 & - & 21,0 & 29,0 & - & - & 0,179 \\
\hline \multicolumn{8}{|c|}{ III. The socioeconomic consequences of risk } & 0,423 & - \\
\hline $\begin{array}{l}\text { 5. Loss of working time, } \% \text { to the } \\
\text { working time fund }\end{array}$ & stimulator & 3,1 & 10,7 & 13,8 & 13,2 & 20,8 & - & - & 0,333 \\
\hline $\begin{array}{l}\text { 6. Loss of labor income, } \% \text { to } \\
\text { their total volume }\end{array}$ & stimulator & 10,7 & 15,1 & - & - & 9,2 & - & - & 0,333 \\
\hline $\begin{array}{l}\text { 7. The rate of change in labor } \\
\text { productivity (GDP per } \\
\text { employee), } \% \text { for the first half of } \\
2020\end{array}$ & destimulator & - & - & 87,1 & - & - & 92,3 & - & 0,334 \\
\hline
\end{tabular}

* the values are calculated as growth/decrease rates in the first half of 2020 compared to the Q4 2019 Source: calculated by the authors

A significant reduction in gross fixed capital formation indicates that the effects of the recession will be long-lasting, since investment resources in the EU countries have decreased by almost $21.0 \%$. As a result of the financial crisis and pandemic, the international trade relations between the countries decreased by $20.0-21.0 \%$.

Ukraine is a European country that implements a strategy of integration into the European space and rapprochement with the EU. The negative consequences of the international economic recession for Ukraine appear to be more intense due to the objective internal and external reasons: the low level of economic development and competitiveness, technical and technological backwardness, unfavorable conditions in international raw material markets, closure of commodity markets etc.

The introduction of the strict quarantine measures by the Cabinet of Ministers of Ukraine in mid-March 2020 due to an outbreak of coronavirus throughout Ukraine, and from the end of April - adaptive quarantine were accompanied by the increase in negative socioeconomic consequences.

The dangerous impact of the COVID-19 pandemic on the socioeconomic situation with the simultaneous spread of the international economic crisis creates a negative synergy effect for the national economy, accompanied by a significant decline in real GDP (Atlantic Council...2020), intensification of socioeconomic crisis in the country and has the serious consequences for the domestic labor market and areas of employment.

The impact of the international financial crisis has caused the decline of macroeconomic indicators of economic development. Thus, for Q1 2020, before the introduction of the strict quarantine regime, real GDP (in $\%$ to the previous quarter) decreased by $1.3 \%$, and per capita - by $0.7 \%$. The negative trends were accompanied by a significant increase in the loss of enterprises - the share of enterprises that received losses only in Q1 increased by $13.6 \%$, and losses increased almost 5 times. Starting with Q2 2020, the financial crisis was compounded by the effects of strict quarantine measures, which significantly increased the intensity of negative trends in Ukraine's economy. Only for Q2 2020, the rate of decline in real GDP (in 2016 prices) reached $11.4 \%$, and its level (per capita), respectively, decreased by $10.8 \%$. For Q1 household spending for final consumption due to inertia still increased, and for Q2 it fell by $10.4 \%$. There is an unfavorable state regarding a decline by $45,0 \%$ of gross fixed capital formation for six months, which virtually eliminates the possibility of investing in the economy by own expenses for the next few years. 
The change of the economic sentiment indicator (ESI) ${ }^{3}$ shows that in Q1 2020, the phase of recession affected such activities as culture and education, hotel and restaurant business, wholesale and retail trade, professional and administrative services, transport, industry. In Q2 and Q3, the phase of deep depression replaced it, which corresponds to the certain stages of the economic development crisis of Ukraine. Almost the same pattern has developed in the EU countries - in Q2 2020, the decrease in ESI was 12.5\%, and in general for six months $-8.9 \%$. In Ukraine, these indicators are significantly lower, which indicates a higher level of economic decline among enterprises.

\subsection{Social consequences of COVID-19}

The negative economic consequences of the impact of the coronavirus crisis are accompanied by increasing risks in the social sphere: decline in population incomes, rise in unemployment, decrease in demand for labor and the number of jobs, increase in poverty.

The analytical material of the International Labor Organization (ILO) ( ILO COVID-19... 2020), dedicated to the impact of the pandemic on the labor market, identifies a massive decline in labor incomes caused by significant losses of working time. According to estimates in the report, for the first three quarters of 2020, the volume of labor income in the whole world, compared to the same period last year, decreased by $10.7 \%$. This happened despite of measures taken by individual states to support them.

Other negative consequences are associated with the significant loss of working time. In the world the loss of working time for Q2 2020 is about 17.3\%, and as for Q3, this indicator can reach $12.1 \%$. Due to the coronavirus pandemic, about 1.6 billion people in the world who work informally may lose their jobs.

The largest losses in the labor market during the quarantine period in the EU countries are caused by the fall in hours worked and the decrease in work attendance. It should be noted that in Q1 2020, in order to assess losses, it is not enough to determine only the level of employment and unemployment, as presented by the ILO concept. This has to do with the fact that at the beginning of the quarantine, all measures to prevent the spread of COVID-19 were focused primarily not on the dismissal of employees, but on the suspension of most economic entities. Under these conditions, workers are not officially unemployed, but fall into the category of "hidden unemployment". To determine all changes and negative effects on the labor market, the EU statistical office determines and provides additional quarterly indicators, which refer to the total labor reserve, the number of part-time employees sent on unpaid or partially paid leave, the total volume index of time worked, etc.

Thus, in 23 EU countries in Q1 2020, the total number of actual hours worked in the age group of 20-64 years at the main job decreased by 5.2\% compared to Q4 2019. Work absences (in $\%$ to employees) are 12.0\%, which is 2.3\% higher than in Q4 2019, and the absence of employees at work increased by almost $75.0 \%$. In Q2 2020, due to almost all quarantine measures, compared to Q4 2019, the number of actual hours worked decreased

\footnotetext{
${ }^{3}$ ESI is calculated in accordance with the methodology for calculating indicators of expectations, which was approved by the State Statistics Committee on 30/12/2014 № 411 (as amended) (The methodology...2014).
} 
by $13.5 \%$ and employment decreased by 3.2\%. Officially, the unemployment rate in Q1 even decreased by 0.1 percentage points, from 6.4\% (Q4 2019) to 6.3\% (Q1 2020), and only in Q2 2020, the employment rate decreased by 3.2\% (Table 2). According to ILO estimates, the global loss of working time in Q2 2020 amounted to $17.3 \%$, in Q3 - 12.1\%, when according to the expert estimates in Q4 they can also range within $9.0 \%$.

Table 2. Characteristics of unemployment, loss of working time and labor income in the world labor markets and in the EU countries for I-III quarters of 2020

\begin{tabular}{|c|c|c|c|c|}
\hline \multirow{2}{*}{ Indicators } & \multirow{2}{*}{ Q4 2019} & \multicolumn{3}{|c|}{2020} \\
\hline & & Q1 & Q2 & Q3 \\
\hline \multicolumn{5}{|l|}{ In the EU countries: } \\
\hline 1. Unemployment level, $\%$ & 6,4 & 6,3 & 6,6 & \\
\hline 2. Work absences, $\%$ of employees & 9,7 & 12,0 & & \\
\hline $\begin{array}{l}\text { 3. Change in the number of actual hours worked at the } \\
\text { main job, in \% regarding Q4 } 2019\end{array}$ & - & $-5,2$ & $-13,8$ & \\
\hline 4. Absence at work, \% regarding Q4 2019 & - & 175,0 & & \\
\hline 5. Employment growth/decrease rates, $\%$ & - & $-3,2$ & & \\
\hline \multicolumn{5}{|l|}{$\begin{array}{l}\text { In the world labor market, according to ILO estimates } \\
\text { (ILO Monitor...2020): }\end{array}$} \\
\hline $\begin{array}{l}\text { 1. Growth/decrease in labor income in the world, } \\
\% \text { by December } 2019\end{array}$ & & & & $-10,7$ \\
\hline 2. World loss of working time, $\%$ to the total working time fund & & & 17,3 & 12,1 \\
\hline
\end{tabular}

Source: compiled by the authors according to the latest official data

The main negative trends of the labor market in Ukraine generally coincide with the mentioned above world characteristics, but for objective reasons (low level of economic development, significant volumes of labor migration, spread of shadow and informal employment, etc.) cause more intense level of their manifestation and scope (Table 1). Nowadays in Ukraine there are no official statistics on the assessment of loss of working time, therefore they can be calculated only conditionally with certain restrictions. According to the author's calculations for the contingent of the employed population, the loss of working time is about $20.8 \%$ of the working time fund.

According to the estimates of the expected changes in the volume of production and the number of employed population, the possible amount of dismissals in Ukraine could reach about 1224.5 thousand people. But as a result of strict quarantine measures, the actual number of workers who lost their jobs completely or partially was significantly higher.

As in most European countries, given that in Q1 2020 the main shifts in the labor market are due to the impact of the international financial crisis with a certain lag of delay in the impact on the labor sector ${ }^{4}$, employment compared to Q4 2019 did not change at a slight $(-1.95 \%)$ decrease in the number of employees and the unemployed $(-1.0 \%)$. All the negative shifts in the labor market have already manifested themselves significantly in Q2 2020, when, simultaneously with the economic recession, strict quarantine measures began to be applied to the labor market. The total number of employees decreased by 326.9

\footnotetext{
${ }^{4}$ According to certain ratios of the change speed of employment and economic development indicators, this lag can be estimated at least one or two quarters.
} 
thousand people or $4.1 \%$, while this decrease (by 53.6 thousand people) lasts in JulyAugust 2020. The largest losses of the contingent of employees for the I-II quarters formed by types of activities on temporary accommodation and catering $(-16.6 \%)$, provision of other services $(-5.9 \%)$, information and telecommunications and activities in the field of administrative and public services $(-5.5 \%)$. The number of employees in real estate, arts, sports, entertainment, recreation, health care and social services decreased by $3.0-4.0 \% 0^{5}$.

The peculiarities of the change in the total number of dismissed employees include a significant difference in the rate of decline in the employed population and employees (full-time contingent employed under administrative and legal contracts and employees outside the payroll). If in general the reduction of the contingent of the employed population in Q2 2020 was $5.3 \%$, then as for employees it is only $2.2 \%$.

The ILO (ILO Monitor...2020) estimates that the loss of working time is manifested in higher levels of unemployment and inactivity ${ }^{6}$, with inactivity increasing to a greater extent than unemployment. This pattern is confirmed by the calculated loss of working time ${ }^{7}$ in the national labor market. In the total amount of losses, losses due to underemployment and sending on unpaid leave is about $71.0 \%$ - this contingent by definition generally corresponds to the concept of "inactivity".

During the study period, the profit and wages of employees of small enterprises decreased due to the deterioration of their financial condition. The wages paid to Ukrainians abroad also decreased due to the return of some migrants to Ukraine and the restriction of new departures to other countries. Both those dismissed under quarantine conditions and those who were in a situation of forced underemployment or work breaks suffered from the significant losses of income. The Center for Economic Strategy (Ninko 2020) estimates that there were about 3.1 million people in hidden unemployment at the quarantine climax. These people have lost their wages partially or completely while remaining formally employed. Two opposite processes which have developed in system of payment should be mentioned. In the EU countries in Q2 2020, when COVID-19 control measures were quite widespread, hourly labor costs increased by $4.1 \%$ in the Eurozone and by $4.2 \%$ in the EU countries as a whole. This increase in hourly wages was mainly due to moderate compensation in a structure not directly related to payment - the matter concerns the introduction of tax breaks and subsidies introduced by the EU governments to support businesses affected by the crisis. In the EU countries, the types of economic activity that had the highest growth rates of hourly wages include the following: accommodation and food activities $(+13.5 \%)$, arts, recreation, entertainment $(+12.5 \%)$, transport and storage $(+8.0 \%)$. On the other hand, workers who lost their jobs completely or partially or were transferred to part-time employment lost their earnings, which significantly affected the decline in livelihood means and life support.

\footnotetext{
5 According to the State Statistics Service of Ukraine

${ }^{6}$ The difference between unemployment and inactivity is based on the actions taken by people when losing their employment completely or partially. That is, if a person does not have a job, but is looking for it and is open to job offers, then it is "unemployment", if a person does not have a job and is not looking for it, then it is called "inaction".

7 The total number of losses of working time is estimated by the number of unemployed, including hidden unemployment, which are determined by the results of a survey.
} 
A significant decline in the income of Ukrainians was accompanied by a change in their structure. Thus, only for Q1 2020 the share of wages in total population incomes decreased by $4.6 \%$ and was only $45.4 \%$ in $\mathrm{Q} 2$, the share of profit and mixed income decreased by 0.3 percentage points. At the same time, the share of social assistance and other current transfers received increased by $5.1 \%$.

Taking into account the loss of wages by employees who were dismissed during a period of severe quarantine or lost their income completely or partially due to hidden unemployment, it is possible to determine the amount of lost income without taking into consideration payments and compensations planned by the Government of Ukraine (Table 3).

Table 3. Estimation of losses of wages and income for the second quarter of 2020

\begin{tabular}{|l|c|c|}
\hline Indicators & $\begin{array}{c}\text { According to } \\
\text { official statistics } \\
\text { on the staff } \\
\text { (lower limit) }\end{array}$ & $\begin{array}{c}\text { According to public opinion } \\
\text { polls (on contingent of } \\
\text { employed population) } \\
\text { (upper limit) }\end{array}$ \\
\hline $\begin{array}{l}\text { Wage losses: } \\
\text { - upon dismissal, UAH million }\end{array}$ & 6476,5 & 22014,0 \\
\hline - upon part-time employment & 898,3 & 14260,0 \\
\hline - upon unpaid leave & 9580,7 & 36274,0 \\
\hline Total & 0,455 & 0,455 \\
\hline - the share of wages in total income & 394713,0 & 394713,0 \\
\hline $\begin{array}{l}\text { - wage volumes in the income of the population, UAH } \\
\text { million }\end{array}$ & 0,153 & 0,153 \\
\hline $\begin{array}{l}\text { - the share of profit and mixed income, in the population } \\
\text { income }\end{array}$ & 132730,0 & 132730,0 \\
\hline $\begin{array}{l}\text { - volumes of profit and mixed income, in population } \\
\text { income, UAH million }\end{array}$ & 2,43 & \multirow{2}{*}{6} \\
\hline $\begin{array}{l}\text { - the specific weight of wage losses in relation to the } \\
\text { amount of wages in income, \% (for full-time employees) }\end{array}$ & - & 6,9 \\
\hline $\begin{array}{l}\text { - the specific weight of wage losses in relation to wages, } \\
\text { profits and mixed income in population incomes, \% (for } \\
\text { the employed population) }\end{array}$ & & \\
\hline
\end{tabular}

Source: calculated by the authors

The loss of income is accompanied by an increase in poverty. According to research conducted by scientists from the Institute of Demography and Social Research named after M.V. Ptukha of the National Academy of Sciences of Ukraine, by the end of 2020 the poverty rate in the country may increase to $45 \%$, given that quarantine measures would end completely or partially in June, which actually did not happen (Cherenko et al. 2020). Among the most affected categories of the population are workers with a low level of education and qualifications. The consequences of falling incomes also have a significant impact on the ability to receive social transfers, especially for those for whom transfers are the main source of income. This impact will, of course, be with a certain lag of delay, for example, in 2-3 quarters, because then the question about possible filling the budgets of all levels will arise. According to estimates in the study, with a decline in GDP of up to $10 \%$, the income situation can still be controlled, but even under these conditions, families with non-diversified sources of income and a large number of dependents will suffer the 
most. But even such a level of falling GDP (up to 10\%) can have serious consequences in the current situation, which are accompanied by growing poverty in Ukraine. The crisis may increase the risk of poverty among those who have traditionally been at their worst conditions. At the same time, the reduction of income in more prosperous families will generally not have extreme consequences, they will not be among the poor population, but their consumer opportunities will be significantly narrowed.

The actual volume of GDP decline in the first half of 2020 was much higher than defined as uncritical, which significantly affected the decline in income, and given the strengthening of quarantine measures, from September to October we can expect a significant increase in poverty in the country by various criteria of its definition both for 2020 and the next year.

\section{Methodology}

The generalization of the negative consequences of the impact of the international financial crisis and quarantine measures on the sphere of social and labor relations can be determined on the basis of a quantitative assessment of social risks. The comparative assessment of labor risks in Ukraine and the EU countries is based on the construction of indexes of change in the respective risks, which correspond to the basic principles of building the European System of Social Indicators (ESSI) (Novikova et al. 2020; Saienko 2004; Sydorchuk 2018). The main starting points for determining the relevant risks are as follows:

- the main components of social risks are determined, which are related to the economic conditions of risk formation, their direct manifestation in the sphere of unemployment and socioeconomic consequences of such manifestation;

- the system of indicators for measuring certain components is formed, while their number and content characteristics are limited by the possibilities of comparability according to the method of determination of the EU countries and Ukraine;

- the corresponding sub-indexes $\left(I_{i}\right)$ are determined for each component, which are summarized in the aggregate risk index of the social and labor sphere $\left(I_{S L S}\right)$

$I_{i}=\sqrt[\sum W_{j}]{\prod_{j=1}^{n_{i}} \frac{x_{i j}^{U k r *} W_{j}}{x_{i j}^{E U}}}$

[formula 1] ${ }^{8}$,

where $I_{i}$ - sub-index for the i-th component;

$i=1,2,3$;

$x_{i j}^{U k r}, x_{i j}^{E U}-\mathrm{j}$-th indicator for determining the $\mathrm{i}$-th sub-index, respectively, for Ukraine and the EU countries;

$\mathrm{j}$ - the number of the measurement indicator of the i-th subindex;

$j=\overline{1, n_{l}}$;

$n_{i}$ - the number of indicators for the $i$-th component;

$8 *$ Based on the fact that the indicators by the EU countries are selected as a basis for comparison, with the inverse effect on changes in risk levels, the ratio is calculated as the inverse: $\frac{x_{i j}^{E U}}{x_{i j}^{U k r}}$ 
$W_{j}^{* *}$ - the weight of the $\mathrm{j}$-th indicator is determined by the share of persons on the set of which its manifestation or action is possible?

The aggregate risk comparison index is defined as follows:

$I_{\text {SLS risks }}=\sqrt[\sum W_{i}]{\prod_{i=1}^{3} I_{i}^{W_{i}}}$

[formula 2],

where $W_{i}$ - weighting coefficients of the i-th component.

Provided that $I_{i}>100 \%$ (or $I_{\text {SLS risks }}>100 \%$ ) the level of relevant risk in Ukraine significantly exceeds its value in the EU countries and vice versa.

\section{Results}

The sub-index of changes in the economic conditions for the formation of risks in the system of social and labor relations ( $I_{1}$ or $\left.I_{\text {ec.conditions }}\right)$ includes a comparison of four indicators of measurement for Q2 2020, namely, the growth (decrease) rate of real GDP, through the changes in household expenditures and gross fixed capital formation, as well as the rate of change in economic sentiment of entrepreneurs. All quantitative characteristics of the relevant indicators and their weighting coefficients are given in Table 1.

The sub-index of economic conditions for the formation of risks of social and labor relations will be as follows:

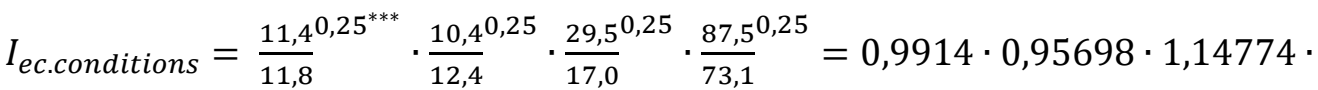

$1,046=1,1410$

Thus, in Ukraine more negative conditions for the formation and manifestation of social risks in the labor sphere have been created. It particularly depends on a significant decline in fixed capital formation and negative trends in economic sentiment. At the same time, it should be noted that the indicator of the change rate of GDP in Ukraine barely differs from the similar indicator in the EU countries, and the situation in Ukraine is even better in terms of changes in household expenditures.

The structure of the sub-index of unemployment risks changes included the following types of risks and indicators of their impact:

- the share of those employed in the industries that have suffered the most from quarantine measures;

- unemployment rate;

- the level of hidden unemployment;

- remote employment;

- informal employment.

The sub-index of changes of unemployment risks $\left(\mathrm{I}_{\text {unemlp.risk }}\right)$ taking into account the relevant weighting coefficients is calculated by the ratio:

$9 * *$ In the given calculations, the weighting coefficients are determined for Ukraine due to the lack of relevant information on the EU countries

$10 * * *$ The weighting coefficients for all indicators are the same $\left(W_{1 j}=0,25\right)$ based on the fact that the effect of these indicators extends to the entire population of the country 


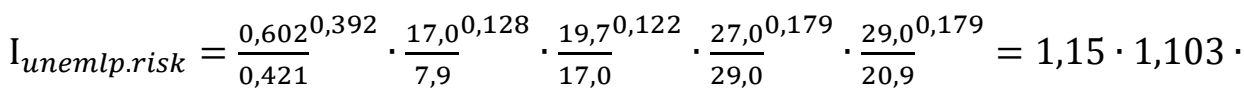

$1,018 \cdot 0,9873 \cdot 1,06=1,351$ or $135,1 \%$

According to the given calculations, in Ukraine the risks of unemployment, which are due to the strict quarantine measures, have a more significant negative impact - they are $35.1 \%$ higher than in the EU countries. Due to the internal structure of sub-index indicators, the largest impact in Ukraine is the significant excess of the share of employed in the types of economic activities most affected by the coronavirus crisis, the unemployment rate is significantly higher (average between official statistics and expert estimates), including hidden one. In the national labor market, the share of informally employed workers is much higher than in the EU countries.

According to the third component, which is related to the assessment of the comparison of the consequences of the manifestation and implementation of social risks, the sub-index ( $\left.I_{\text {conseq }}\right)$ is determined on the basis of the following indicators:

- loss of working time;

- loss of labor income;

- rates of labor productivity.

Based on the fact that the effect of these indicators applies to the entire employed population in the calculations, the weighting coefficients are determined at 0.333 . Under these conditions, the sub-index will be as follows:

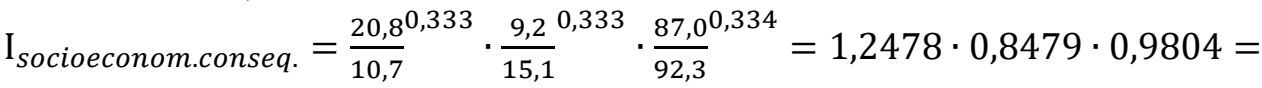

1,037 or $103,7 \%$

In the structure of this sub-index, the main "destructive" factor that significantly exacerbates the economic consequences of risk in Ukraine is the loss of working time their level is almost $25.0 \%$ higher than in the EU countries. In general, the level of socioeconomic consequences of this component is 3.7\% higher in Ukraine compared to the EU countries.

The aggregate index of comparison of risks of social and labor relations, which is calculated on the basis of the given sub-indexes $\left(I_{S L S}\right.$ risks $)$ is determined as follows:

$\mathrm{I}_{\text {SLS risks }}=1,14^{0,281} \cdot 1,351^{0,296} \cdot 1,037^{0,423}=1,0375 \cdot 1,093 \cdot 1,0155=1,152$ or $115,2 \%$

In general, the manifestation of risks that have arisen in the system of social and labor relations in Ukraine is significantly higher than in the EU countries as a whole by $15.2 \%$, with the main reason being the excess of levels of risks that have arisen directly in employment and the labor market in Ukraine, above the relevant indicators for the EU.

\section{Conclusion}

According to the results of risk assessment in the system of social and labor relations in the EU countries and Ukraine, we can identify the most important factors that cause a much higher level of their manifestation directly in Ukraine and in the national labor market compared to other EU countries:

according to the component "Economic conditions of risk formation" it is a significant drop in gross fixed capital formation; 
according to the component "Unemployment risks" it is a significant share of those employed in economic activities, which are most affected by quarantine restrictions in Ukraine. In second place there is a high level of unemployment, including the level of hidden unemployment;

according to the component "Socioeconomic consequences of manifestation and realization of social risks" the main factor influencing the higher level of risk in Ukraine compared to the EU countries is related to the loss of working time due to full, partial and hidden unemployment.

Thus, the algorithm of the proposed method allows to assess the risks in the system of social and labor relations in comparison with the situation in other countries, in particular the EU ones. The analysis of the sub-index components of the formation, manifestation, consequences of risks in the social and labor sphere provides an opportunity to systematize and rank the factors that affect the growth of risks and constrain opportunities for sustainable development. The characterization of labor risks is extremely important in determining the priority of preventive measures and the consequences of changing quarantine restrictions or their extension. Comparing the risks of social and labor relations in different countries contributes to the purposeful study of the experience of those countries that have found effective ways to overcome or reduce risks in the social and economic spheres.

\section{References}

Atlantic Council: Coronavirus can reduce Ukraine's GDP by 15\% (2020). Unian. Retrieved from https://www.unian.ua/economics/finance/10924694-atlantic-council-koronavirus-mozheskorotiti-vvp-ukrajini-na-15.html

Bragazzi, N.L., Dai, H., Damiani, G., Behzadifar, M., Martini, M., \& Wu, J. (2020). How BigData and Artificial Intelligence Can Help Better Manage the COVID-19 Pandemic. International Journal of Environmental Research and Public Health, 17, 3176. DOI: 10.3390/ijerph17093176.

Cherenko, L.M , Poliakova, S.V., Shyshkin, V.S., Reut A.H., Vasyliev, O.A., Kohatko, Yu.L., Zaiats, V.S., Klymenko Yu.A., \& Novosilska, T.V. (2020). The impact of the coronavirus crisis on poverty: the first consequences for the country. Nats. akad. nauk Ukrainy, In-t demohr. ta sots. doslidzh. im. M.V. Ptukhy. pp. 20-22.

Employment - quarterly statistics (2020). Eurostat Statistics Explained. Retrieved from https://ec.europa.eu/eurostat/statistics-explained/index.php?title=Employment - quarterly statistics

ILO (2020). COVID-19: Ban workers in the workplace: COVID-19 pandemic leads to massive loss of earnings. Retrieved from https://www.ilo.org/wcmsp5/groups/public/---dgreports/--dcomm/documents/briefingnote/wcms_755910.pdf

ILO (2020). ILO Monitor: COVID-19 and the world of work. Sixth edition Updated estimates and analysis. Retrieved from https://www.ilo.org/wcmsp5/groups/public/---dgreports/--dcomm/documents/briefingnote/wcms 755910.pdf

KMU (2020). Prohrama stymuliuvannia ekonomiky dlia podolannia naslidkiv COVID-19: «ekonomichne vidnovlennia» (informatsiino-analitychni materialy). Retrieved from https://www.kmu.gov.ua/news/uryad-zatverdiv-z-doopracyuvannyam-programustimulyuvannya-ekonomiki-dlya-podolannya-naslidkiv-epidemiyi-covid-19.

Mahase, E. (2020). Covid-19: death rate is $0.66 \%$ and increases with age, study estimates, Retrieved from https://www.bmj.com/content/369/bmj.m1327.

Novikova, O. \& Shamileva, L. (2020). Evaluation of social and economic insecurity risks for employees during structural transformations in the modern labor market. Social and labor relations: theory and practice, Vol. 10, Iss. 1, 1-10. Doi: 10.21511/slrtp.10(1).2020.01 
Roper, W. (2020). Predicted Unemployment Higher Than Great Depression, Retrieved from https://www.statista.com/chart/21329/highest-unemployment-rates-ever/.

Saienko, Yu. (2004). Methodology and methods of determining integrated social indicators. Kyiv: Institute of Sociology of the National Academy of Sciences of Ukraine.

Sydorchuk, O. (2018). Methodical approaches to measuring economic insecurity in the context of social dangers. Naukovyi visnyk Uzhhorodskoho natsionalnoho universytetu. Seriia: Miəhnarodni ekonomichni vidnosyny ta svitove hospodarstvo, Vol. 18, Part 3, 59-64.

Tran, T.T., Pham, L.T., \& Ngo Q.X. (2020). Forecasting epidemic spread of SARS-CoV-2 using ARIMA model (Case study: Iran). Global Journal of Environmental Science and Management, 6(SI), 1-10.

The methodology for calculating indicators of expectations by the State Statistics Committee on 30/12/2014 № 411 (as amended). Retrieved from http://www.ukrstat.gov.ua/metod_polog/metod_doc /2019/175/m_rido.pdf

Yadav, D., Maheshwari, H., \& Chandra, U., (2020). Outbreak prediction of COVID-19 in most susceptible countries. Global Journal of Environmental Science and Management, 6(SI), 11-20.

Ninko, D. (2020). Bezrabotica ushla v ten skolko ukraincev na samom dele poteryali rabotu iz za karantina. Retrieved from https://delo.ua/econonomyandpoliticsinukraine/karantinnaja-bezrabotica-skolkoukraincev-poter-371140/ 